\title{
Image analysis in the evaluation of the physiological potential of maize seeds ${ }^{1}$
}

\author{
Análise de imagens na avaliação do potencial fisiológico de sementes de milho
}

\author{
Crislaine Aparecida Gomes Pinto ${ }^{2 *}$, Maria Laene Moreira de Carvalho ${ }^{2}$, Dayliane Bernardes de Andrade ${ }^{2}$, Eva \\ Rezende Leite ${ }^{2}$ e Igor Chalfoun ${ }^{3}$
}

\begin{abstract}
The Seed Analysis System (SAS) is used in the image analysis of seeds and seedlings, and has the potential for use in the control of seed quality. The aim of this research was to adapt the methodology of image analysis of maize seedlings by SAS, and to verify the potential use of this equipment in the evaluation of the physiological potential of maize seeds. Nine batches of two maize hybrids were characterised by means of the following tests and determinations: germination, first count, accelerated ageing, cold test, seedling emergence at 25 and $30^{\circ} \mathrm{C}$, and speed of emergence index. The image analysis experiment was carried out in a factorial scheme of 9 batches $\mathrm{x} 4$ methods of analysis of the seedling images (with and without the use of NWF as substrate, and with and without manual correction of the images). Images of the seedlings were evaluated using the average lengths of the coleoptile, roots and seedlings; and by the automatic and manual indices of vigour, uniformity and growth produced by the SAS. Use of blue NWF afffects the initial development of maize seedlings. The physiological potential of maize seeds can be evaluated in seedlings which are seeded on white paper towels at a temperature of $25{ }^{\circ} \mathrm{C}$ and evaluated on the third day. Image analysis should be carried out with the SAS software using automatic calibration and with no correction of the seedling images. Use of SAS equipment for the analysis of seedling images is a potential tool in evaluating the physiological quality of maize seeds.
\end{abstract}

Key words: Zea mays. Vigour. SAS.

RESUMO - Sistema de Análise de Sementes (SAS) é um equipamento de análise de imagem de sementes e plântulas com potencial de utilização no controle de qualidade de sementes. Os objetivos na pesquisa foram adequar uma metodologia de análise de imagens de plântulas de milho pelo SAS, bem como verificar a potencialidade de utilização desse equipamento na avaliação do potencial fisiológico de sementes de milho. Utilizaram-se 9 lotes de 2 híbridos de milho caracterizados pelos testes e determinações: germinação, primeira contagem, envelhecimento acelerado, teste de frio, emergência de plântulas a 25 e $30^{\circ} \mathrm{C}$ e pelo índice de velocidade de emergência. O experimento de análise de imagens foi realizado em esquema fatorial 9 (lotes) X 4 métodos de análise de imagem de plântulas (com e sem o substrato TNT, e com e sem correção manual das imagens). Avaliouse as imagens das plântulas pelos comprimentos médios do coleóptilo, raiz e plântulas; e pelos índices de vigor automático e manual, uniformidade e crescimento, fornecido pelo SAS. O uso do TNT azul interfere no desenvolvimento inicial das plântulas de milho. O potencial fisiológico de sementes de milho pode ser avaliado em plântulas obtidas em semeadura em papel toalha branco, a temperatura de $25^{\circ} \mathrm{C}$ com avaliação ao terceiro dia. A análise da imagem deve ser feita com a calibração automática pelo software SAS, sem correção da imagem das plântulas. A análise de imagem de plântulas pelo equipamento SAS é uma ferramenta potencial na avaliação da qualidade fisiológica de sementes de milho.

Palavras-chave: Zea mays. Vigor. SAS.

DOI: $10.5935 / 1806-6690.20150011$

* Autor para correspondência

'Recebido para publicação em 04/02/2014; aprovado em 04/12/2014

Parte da Dissertação de Mestrado da primeira autora apresentada ao Programa de Pós-Graduação em Agronomia/Fitotecnia, da Universidade Federal de Lavras/UFLA

${ }^{2}$ Departamento de Agricultura, Setor de Sementes, Universidade Federal de Lavras/UFLA, Cx. Postal 3037, Lavras-MG, Brasil, 37.200-000, crislaine. pinto@yahoo.com.br, mlaenemc@dag.ufla.br, dayliane@posgrad.ufla.br, evarezendeleite@hotmail.com

${ }^{3}$ Empresa Tbit Sistemas e Tecnologias, Incubadora de Empresas de Base Tecnológica (Inbatec), Universidade Federal de Lavras, Campus Universitário. Lavras- MG, Brasil, 37.200-00, igor@tbit.com.br 


\section{INTRODUCTION}

Maize is a very important crop for the economy, being the cereal which is most produced in the country (CONAB, 2013). Investment in technologies to ensure high productivity, including the use of high-quality seeds, is extremely profitable for the producers of the cereal.

Seed quality is guaranteed by minimum standards, which are required for the certification process. The physiological potential of batches is evaluated using the results of germination testing (BRASIL, 2013) which, although standardised, does not always reflect the behaviour of seeds in the field.

More sensitive tests, such as those of vigour, can identify less advanced stages of seed deterioration, and can facilitate decisions on the fate or disposal of batches. One of the limitations on the use of these tests is related to the time needed to carry them out and the subjectivity in their evaluation.

Techniques of image analysis, used to assess images of seedlings, can minimise these limitations if adapted to different plant species. Software, such as the Seed Vigour Imaging System (SVIS) developed by Ohio State University (OSU) to evaluate the vigour of lettuce seeds (SAKO et al., 2001), has been used effectively in species of large crops, such as maize (ALVARENGA; MARCOS FILHO; GOMES JUNIOR, 2012; OTONI AND MCDONALD, 2005), soybean (MARCOS FILHO; KIKUTI; LIMA, 2009), peanuts (MARCHI; CICERO; GOMES JUNIOR, 2011) and wheat (SILVA; GOMES JUNIOR; CICERO, 2012).

In Brazil, the Seed Analysis System (SAS), recently developed by Tbit Tecnologia e Sistemas, and used to evaluate the physical and physiological quality of seeds, is now available on the market. Evaluation is made by means of highresolution images, which allow the extraction of information on colour, texture and geometry, besides providing indices for growth rates and uniformity of the seedlings.

SAS shows promise in evaluating the physiological potential of seeds, but there is no research to prove its efficiency in species such as maize. The aims of this research were to adapt a methodology for analysing images of maize seedlings using SAS, and to verify the capacity of this equipment in evaluating the physiological potential of maize seeds.

\section{MATERIAL AND METHODS}

Eighteen batches of maize seeds were used of differing physiological quality, consisting of nine batches (1-9) of Hybrid 1, and nine batches (A-I) of Hybrid
2, both supplied by Dow AgroSciences Industrial Ltda. The research was carried out at the Central Laboratory for Seed Analysis of the Federal University of Lavras (UFLA), and at Tbit Technologies and Systems in Lavras, in the state of Minas Gerais (MG), from February, 2012 to December, 2013.

The experiment was conducted in a completely randomised design employing a $9 \times 4$ factorial scheme for each hybrid under evaluation; 9 batches of maize seeds and 4 methods of image analysis (with and without a coloured substrate and with and without image correction). Four replications of 50 seeds were used in tests for characterisation of the batches, and eight replications of 25 seeds for the methods of image analysis. To analyse the data, means comparison was used (Scott Knott test at 5\% significance), employing the Sisvar software.

\section{Characterisation of the batches}

Water content was determined by the oven method at $105{ }^{\circ} \mathrm{C} \pm 2{ }^{\circ} \mathrm{C}$ for 24 hours (BRASIL, 2009), using 2 replications of $5 \mathrm{~g}$ of seed per treatment. The results were expressed as a percentage.

The germination test was carried out with four replications of 50 seeds per batch. Rolls of paper towels were used as the substrate, moistened with distilled water equivalent to 2.5 times the dry weight of the paper. The rolls were kept in a seed germinator at a temperature of $25 \pm 2{ }^{\circ} \mathrm{C}$, with readings being taken on the fourth (first germination count) and seventh day after sowing (BRASIL, 2009). The results were expressed as a percentage.

The accelerated ageing test was carried out using plastic germination boxes (AOSA, 2009). The seeds for each treatment were distributed over a single layer, and $40 \mathrm{ml}$ of distilled water placed in the bottom of the box. The boxes were covered and kept in a BOD germinator set at $42 \pm 2{ }^{\circ} \mathrm{C}$ for 96 hours; the germination test was then performed. A single reading was taken on the seventh day after sowing, and the percentage of normal seedlings was calculated.

Four replications of 50 seeds were used in the cold test for each treatment. The seeds were sown in plastic trays with a substrate composed of a mixture of earth and sand in the ratio of $2: 1$, moistened with $60 \%$ of its water retention capacity. After sowing, the boxes were kept in a cold chamber at $10^{\circ} \mathrm{C} \pm 2{ }^{\circ} \mathrm{C}$ for 7 days and subsequently placed into a plant growth chamber at $25 \pm 2{ }^{\circ} \mathrm{C}$ for 7 days, when a count of emerged seedlings was taken. The results were expressed as a percentage.

The tests for seedling emergence were carried out at temperatures of 25 to $30^{\circ} \mathrm{C}$. For each test, four replications of 50 seeds were used per treatment. The seeds were sown 
in a compound substrate mixture of soil and sand in the ratio of $2: 1$, moistened with $60 \%$ of its water retention capacity. Readings were taken every day to calculate the Speed of Emergence Index (SEI), counting the number of emerged seedlings that day. The final reading was taken on the 15th day, when seedling emergence stabilised. The results were expressed as a percentage of emerged seedlings.

\section{Image analysis methodology using SAS}

To obtain images of the seedlings, germination tests were carried out on a paper towel substrate, with and without the addition of a substrate of blue, non-woven fabric (NWF), in a roll moistened with water equivalent to 2.5 times its weight. Eight replications of 25 seeds per treatment were used for each test. Blue-coloured NWF was used to enable greater contrast between the roots and the substrate. Seeds were distributed in two rows (one in the upper part, and one in the middle third of the paper) and arranged with the scutellum exposed and the radicle facing the bottom of the paper. The rolls were then placed in a seed germinator set at $25^{\circ} \mathrm{C} \pm 2{ }^{\circ} \mathrm{C}$ for three days, when the images were captured.

Image capture in both germination tests was done with a professional, high-resolution camera contained in the collection chamber of the SAS equipment. Colour calibration of the background used the CIELab colour model, with a luminosity of 0 to 100 , dimension "a" of -120 to 120 , and dimension "b" of -120 to -30 . Image capture of the seedlings without the NWF substrate was done by carefully removing the seedlings from the substrate and placing them in the tray contained in the collection chamber of the SAS; the roll of paper towels with the NWF was opened directly into the tray to capture the images.

Automatic calibration of the formula for vigour using SAS was done using multivariate regression, which relates the value of the cold test, used as default, to the value for the vigour index calculated by the equipment. A calibration was performed for each hybrid. The results for the weight of the parameters contained in the formulas described below (equations 1, 2 and 3) were defined for each calibration.

Growth Index $=\min \left(w_{h} * l_{h}+w_{r} * l_{r}, 1000\right)$

Uniformity Index $=\max \left(1000-\left(w_{S h} * s_{h}+w_{S r} * s_{r}+s_{\text {total }}+\right.\right.$ $\left.w_{S r / h} * s_{r / h}\right)-w_{D} *$ no. of dead seeds, 0$)$

$\underline{\text { Vigour Index }}=p_{G}$ growth $+p_{U}$ uniformity

where: $l_{h}$ and $l_{r}=$ means for the sample of the lengths of the hypocotyl and root; $s_{h}, s_{r}, s_{\text {total }}$ e $s_{r} h=$ standard deviation of the of hypocotyl length, root length, total length, and of the root to hypocotyl ratio; $p_{\mathrm{G}}$ e $p_{\mathrm{U}}=$ parameter weight for growth and uniformity; $w=$ parameter weight.

All the images were subsequently reanalysed using two calibrations for each hybrid: automatic calibration using SAS and manual calibration. For manual calibration, the same weights were used for the parameters as in the SVIS software (Table 1); the values for the weight of growth and uniformity were 70 and $30 \%$ respectively.

Table 1 - Weight values of fixed parameters in formulas for calculating the indices of Vigour, Growth and Uniformity with the SVIS software

\begin{tabular}{lc}
\hline \multicolumn{1}{c}{ Parameter } & Weight \\
\hline Growth $(w C)$ & Variable \\
Uniformity $(w U)$ & Variable \\
Length of hypocotyl $\left(w l_{h}\right)$ & 2.5 \\
Length of root $\left(w l_{r}\right)$ & 5.0 \\
$\begin{array}{l}\text { Standard deviation of hypocotyl } \\
\text { length }\left(w s_{h\urcorner}\right)\end{array}$ & 0.75 \\
$\begin{array}{l}\text { Standard deviation of root length } \\
\left(w s_{r}\right)\end{array}$ & 0.5 \\
$\begin{array}{l}\text { Standard deviation of total length } \\
\left(w s_{\text {total }}\right)\end{array}$ & 2.5 \\
$\begin{array}{l}\text { Standard deviation of the hypocotyl } \\
\text { length to root length ratio }\left(w s_{r / h}\right)\end{array}$ & 50 \\
Number of dead seeds $(w D)$ & 0 \\
\hline Source: McDonald $e t a l, 2008$ &
\end{tabular}

After reanalysis, the average values for root, coleoptile and seedling length were recorded together with the vigour indices; for the images reanalysed by manual calibration, the growth and uniformity indices were also noted.

\section{RESULTS AND DISCUSSION}

\section{Characterisation of the batches}

The values obtained in determining the water content of the nine batches of each hybrid were similar, with there being a variation of from 10.5 to $10.9 \%$ for the batches of Hybrid 1, and from 9.6 to $10.0 \%$ for the batches of Hybrid 2. According to Tekrony (2003), uniformity in moisture content between batches is important for getting 
consistent results when evaluating the physiological potential of seeds.

The results from the characterisation of the 9 batches of Hybrid 1 are shown in Table 2. It can be seen that germination for these batches was over $92 \%$. However, the germination test made it possible to classify the nine batches into two levels of physiological potential, with batches 4, 5 and 6 showing the highest values for germination. The results for vigour in batches of this hybrid using tests of accelerated ageing, cold and seedling emergence were greater than $85 \%$, which is the minimum standard established for germination in commercial batches of maize seeds (BRASIL, 2013).

All the vigour tests used in characterisation identified differences in vigour among the nine batches, with lots 4, 5 and 6 standing out as being of superior vigour, except in the test for seedling emergence at $30{ }^{\circ} \mathrm{C}$, where there was no separation into levels of vigour for any of the batches. Hybrid 1 displays high-performance characteristics in the field under high temperature conditions, and suggestions by the production company of the ideal region for sowing the hybrid includes areas of higher ambient temperature. These characteristics may explain why the test of seedling emergence at $30{ }^{\circ} \mathrm{C}$ did not detect any differences in emergence among the 9 batches. According to Tekrony, Egli and Wickham (1989), under ideal conditions of germination, vigour does not affect emergence in batches of maize seed.

The vigour tests involving germination speed separated the nine batches of Hybrid 1 into different levels of vigour (Table 2). However, there was variation in batch classification at intermediate and low vigour. This variation may be explained by the greater individual variation among seeds from batches of average physiological potential. The greatest individual variation between seeds of any one batch can be seen in batches of medium vigour, since for most species, as in the soybean (ILLIPRONTI JUNIOR, 1997), the more homogeneous batches are the more vigorous. As the process of determination takes place, the individual variation between the seeds increases.

In characterising the nine batches of Hybrid 2, described in Table 3, variation can be seen in the classification of the batches into levels of physiological potential by the tests employed. Performance of the batches can vary between tests for physiological seed evaluation, since these tests assess different characteristics. Similar results were obtained by Caliari e Silva (2001) and Fessel et al. (2003), who found differences in the performance of batches of maize seeds, which depended on the vigour tests used in evaluating the physiological potential.

With the test for germination it was possible to classify the batches into two levels of physiological potential, with batches $\mathrm{B}$ and $\mathrm{C}$ showing lower germination rates than the other batches. The low germination of these batches was primarily due to the high number of seedlings infected by fungi. However, it can be seen that this did not happen in the tests for seedling emergence. The temperatures used in the tests for seedling emergence are probably ideal for germination in the seeds of Hybrid 2. According to Pinho et al. (1995), under ideal conditions for germination, the seedlings emerge quickly, escaping the action of pathogens present in the seeds, however the

Table 2 - Mean results obtained when evaluating the physiological potential of maize seeds in nine batches of Hybrid 1 with the tests for: First germination count (1st C), Germination (G), Accelerated Ageing (AA), Cold Test (CT), Seedling emergence at 25 C (E25), Seedling emergence at $30{ }^{\circ} \mathrm{C}$ (E30), Speed of Emergence Index of the seedlings at $25{ }^{\circ} \mathrm{C}$ (SEI 25) and Speed of Emergence Index of the seedlings at $30{ }^{\circ} \mathrm{C}$ (SEI 30), UFLA, Lavras, MG, Brazil, 2014

\begin{tabular}{ccccccccc}
\hline Batch & $1 \mathrm{st} \mathrm{C}(\%)$ & $\mathrm{G}(\%)$ & AA $(\%)$ & CT $(\%)$ & E25 (\%) & E30 (\%) & SEI 25 & SEI 30 \\
\hline 1 & $76 \mathrm{c}$ & $92 \mathrm{~b}$ & $85 \mathrm{~b}$ & $89 \mathrm{~b}$ & $97 \mathrm{~b}$ & $98 \mathrm{a}$ & $15.35 \mathrm{~b}$ & $15.92 \mathrm{~b}$ \\
2 & $77 \mathrm{c}$ & $93 \mathrm{~b}$ & $91 \mathrm{~b}$ & $91 \mathrm{~b}$ & $95 \mathrm{c}$ & $95 \mathrm{a}$ & $15.12 \mathrm{~b}$ & $15.68 \mathrm{~b}$ \\
3 & $78 \mathrm{c}$ & $94 \mathrm{~b}$ & $93 \mathrm{a}$ & $89 \mathrm{~b}$ & $96 \mathrm{~b}$ & $95 \mathrm{a}$ & $15.22 \mathrm{~b}$ & $15.88 \mathrm{~b}$ \\
4 & $89 \mathrm{a}$ & $97 \mathrm{a}$ & $96 \mathrm{a}$ & $94 \mathrm{a}$ & $99 \mathrm{a}$ & $98 \mathrm{a}$ & $16.01 \mathrm{a}$ & $16.41 \mathrm{a}$ \\
5 & $86 \mathrm{a}$ & $96 \mathrm{a}$ & $95 \mathrm{a}$ & $95 \mathrm{a}$ & $99 \mathrm{a}$ & $99 \mathrm{a}$ & $16.40 \mathrm{a}$ & $16.66 \mathrm{a}$ \\
6 & $90 \mathrm{a}$ & $97 \mathrm{a}$ & $97 \mathrm{a}$ & $94 \mathrm{a}$ & $99 \mathrm{a}$ & $99 \mathrm{a}$ & $16.05 \mathrm{a}$ & $16.71 \mathrm{a}$ \\
7 & $82 \mathrm{~b}$ & $93 \mathrm{~b}$ & $89 \mathrm{~b}$ & $88 \mathrm{~b}$ & $95 \mathrm{c}$ & $95 \mathrm{a}$ & $14.68 \mathrm{c}$ & $15.44 \mathrm{c}$ \\
8 & $77 \mathrm{c}$ & $93 \mathrm{~b}$ & $86 \mathrm{~b}$ & $86 \mathrm{~b}$ & $96 \mathrm{~b}$ & $95 \mathrm{a}$ & $14.67 \mathrm{c}$ & $15.36 \mathrm{c}$ \\
9 & $82 \mathrm{~b}$ & $95 \mathrm{~b}$ & $88 \mathrm{~b}$ & $87 \mathrm{~b}$ & $97 \mathrm{~b}$ & $96 \mathrm{a}$ & $14.98 \mathrm{~b}$ & $15.52 \mathrm{c}$ \\
\hline $\mathrm{CV}(\%)$ & 3.99 & 1.86 & 5.73 & 3.54 & 1.25 & 4.00 & 2.05 & 1.66 \\
\hline
\end{tabular}

* Means followed by the same letter in a column do not differ statistically at a significance level of 5\% by Scott-Knott test 
Table 3 - Mean results obtained when evaluating the physiological potential of maize seeds in nine batches of Hybrid 2 with the tests for: First germination count (1st C), Germination (G), Accelerated Ageing (AA), Cold Test (CT), Seedling emergence at 25 C (E25), Seedling emergence at $30{ }^{\circ} \mathrm{C}$ (E30), Speed of Emergence Index of the seedlings at $25{ }^{\circ} \mathrm{C}$ (SEI 25) and Speed of Emergence Index of the seedlings at $30{ }^{\circ} \mathrm{C}$ (SEI 30), UFLA, Lavras, MG, Brazil, 2014

\begin{tabular}{crrrrrrrr}
\hline Batch & 1 st C (\%) & G $(\%)$ & AA $(\%)$ & CT $(\%)$ & E25 (\%) & E30 (\%) & SEI 25 & SEI 30 \\
\hline $\mathrm{A}$ & $61 \mathrm{c}$ & $93 \mathrm{a}$ & $86 \mathrm{a}$ & $94 \mathrm{a}$ & $96 \mathrm{a}$ & $97 \mathrm{a}$ & $13.91 \mathrm{a}$ & $13.92 \mathrm{a}$ \\
$\mathrm{B}$ & $62 \mathrm{c}$ & $88 \mathrm{~b}$ & $91 \mathrm{a}$ & $87 \mathrm{a}$ & $96 \mathrm{a}$ & $96 \mathrm{a}$ & $13.91 \mathrm{a}$ & $13.79 \mathrm{a}$ \\
$\mathrm{C}$ & $65 \mathrm{c}$ & $89 \mathrm{~b}$ & $89 \mathrm{a}$ & $92 \mathrm{a}$ & $96 \mathrm{a}$ & $95 \mathrm{a}$ & $13.93 \mathrm{a}$ & $13.78 \mathrm{a}$ \\
$\mathrm{D}$ & $69 \mathrm{~b}$ & $94 \mathrm{a}$ & $83 \mathrm{~b}$ & $79 \mathrm{~b}$ & $96 \mathrm{a}$ & $96 \mathrm{a}$ & $13.77 \mathrm{a}$ & $13.79 \mathrm{a}$ \\
$\mathrm{E}$ & $61 \mathrm{c}$ & $94 \mathrm{a}$ & $77 \mathrm{~b}$ & $80 \mathrm{~b}$ & $97 \mathrm{a}$ & $95 \mathrm{a}$ & $13.83 \mathrm{a}$ & $13.67 \mathrm{a}$ \\
$\mathrm{F}$ & $70 \mathrm{~b}$ & $95 \mathrm{a}$ & $82 \mathrm{~b}$ & $80 \mathrm{~b}$ & $98 \mathrm{a}$ & $97 \mathrm{a}$ & $13.94 \mathrm{a}$ & $13.76 \mathrm{a}$ \\
$\mathrm{G}$ & $71 \mathrm{~b}$ & $94 \mathrm{a}$ & $78 \mathrm{~b}$ & $91 \mathrm{a}$ & $96 \mathrm{a}$ & $95 \mathrm{a}$ & $13.93 \mathrm{a}$ & $13.75 \mathrm{a}$ \\
$\mathrm{H}$ & $75 \mathrm{~b}$ & $94 \mathrm{a}$ & $75 \mathrm{~b}$ & $88 \mathrm{a}$ & $96 \mathrm{a}$ & $95 \mathrm{a}$ & $13.85 \mathrm{a}$ & $13.69 \mathrm{a}$ \\
$\mathrm{I}$ & $82 \mathrm{a}$ & $92 \mathrm{a}$ & $83 \mathrm{~b}$ & $93 \mathrm{a}$ & $95 \mathrm{a}$ & $97 \mathrm{a}$ & $13.81 \mathrm{a}$ & $13.86 \mathrm{a}$ \\
\hline $\mathrm{CV}(\%)$ & 6.92 & 2.35 & 5.73 & 4.62 & 1.47 & 1.48 & 1.78 & 1.39 \\
\hline
\end{tabular}

* Means followed by the same letter in a column do not differ statistically at a significance level of $5 \%$ by Scott-Knott test

same does not take place in germination tests carried out on a paper substrate.

With the cold test it was possible to detect that batches D, E and F are of a lower physiological potential than the other batches. In the accelerated ageing test, in addition to these three batches, lots $\mathrm{G}, \mathrm{H}$ and I were also classified as having low vigour. The accelerated ageing test was more sensitive in identifying low vigour in batches of this maize hybrid. However, both in the cold and accelerated ageing tests, batches A, B and $\mathrm{C}$ were superior to batches $\mathrm{D}, \mathrm{E}$ and $\mathrm{F}$.

\section{Automatic calibration}

After the capture and initial analysis of the seedling images, automatic calibration using SAS was carried out for each hybrid. Batches 5, 7 and 8 were randomly selected for Calibration 1 (Hybrid 1), and lots A, F and I for Calibration 2 (Hybrid 2). Calibration was performed based on the results of the cold test: 95,88 , and $86 \%$ for batches 5, 7, 8, and 94, 80 and $93 \%$ for batches A, F and I respectively. The weights of the formulas for calculating the vigour index, which were obtained by automatic calibration using SAS, are shown in Table 4.

Table 4 - Weights of the parameters of the formula for vigour, generated by automatic calibration using SAS, UFLA, Lavras, MG, Brazil, 2014

\begin{tabular}{lcc}
\hline \multicolumn{1}{c}{ Parameter } & \multicolumn{2}{c}{ Weight } \\
\cline { 2 - 3 } & Hybrid 1 & Hybrid 2 \\
\hline Growth $(w C)$ & 83.85629072 & 108.4964549 \\
Uniformity $(w U)$ & 83.85629072 & 108.4964549 \\
Length of hypocotyl $\left(w l_{h}\right)$ & -2.823343321 & 9.322130566 \\
Length of root $\left(w l_{r}\right)$ & 1.762574061 & -2.252439132 \\
Standard deviation of hypocotyl length $\left(w s_{h\urcorner}\right)$ & 15.69882055 & 3.365555998 \\
Standard deviation of root length $\left(w s_{r}\right)$ & 8.572735849 & -6.881685425 \\
Standard deviation of total length $\left(w s_{\text {total }}\right)$ & -11.61613778 & -0.279812909 \\
Standard deviation of the hypocotyl length to root length ratio $\left(w s_{r h h}\right)$ & 0.016115942 & -2.058411161 \\
Number of dead seeds $(w D)$ & 0.788050143 & 3.716112821 \\
\hline
\end{tabular}


The efficiency of the calibration was verified by comparing the cold test results with the vigour index obtained automatically using SAS. Proximity of the cold test values to the vigour index calculated using SAS can be seen in the batches selected for calibration of Hybrid 1 (a) and Hybrid 2 (b), with Calibration 1 displaying hits of $98.4 \%$ and Calibration 2 of $96.9 \%$.

\section{Image Analysis}

After defining the weights of the formulas for automatic calculation of the vigour index, reanalysis of the images was carried out in two ways: the first using the weights defined in automatic calibration using SAS, where the calculated vigour index was designated "automatic"; and the second using the weights of the formula for vigour as set by the method employing the SVIS equipment (Table 1), designated "manual", with weights of $70 \%$ for growth and $30 \%$ for uniformity.

With Hybrid 1, the methods used for image analysis affected the nine batches in a similar way for the variables analysed by the SAS, except for mean root length, where variation in batches $4,5,6,7$ and 8 depended on the method used for evaluation (Table 5). In general for these five batches, greater root growth was seen in the methods using no NWF and with correction. This indicates that the use of blue NWF as a way of improving colour contrast between the maize roots and the substrate may be unnecessary.

For most of the batches image correction had no effect on the results, indicating the efficiency of the SAS equipment in identifying the roots of the maize seedlings, and reducing the time required to get the
Figure 1 - Results of automatic calibration using SAS: (a) calibration of Hybrid 1 and (b) calibration of Hybrid 2, UFLA, Lavras, MG, Brazil, 2014

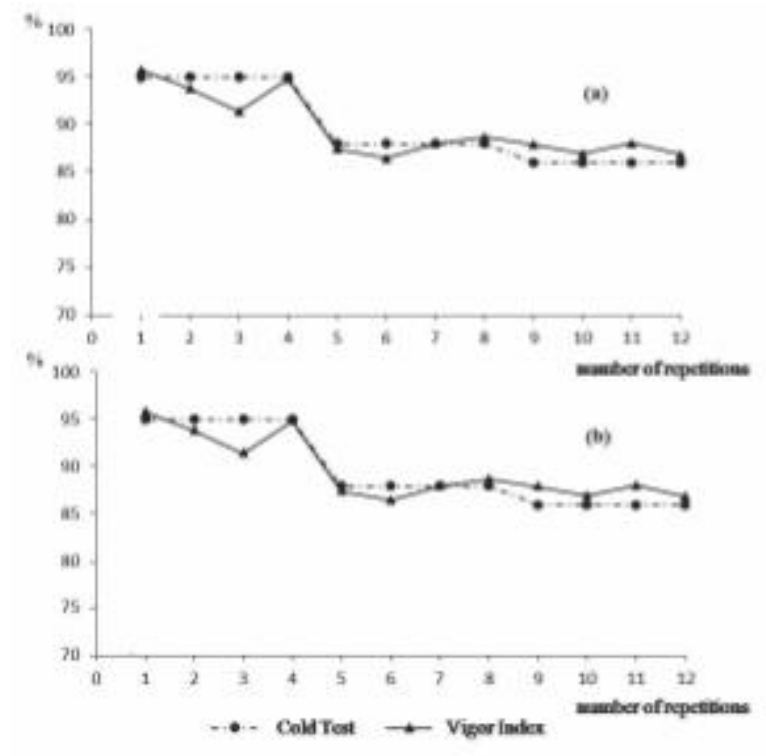

results of image analysis with this equipment. Teixeira, Cícero and Dourado Neto (2006), using a processing routine of the "Scil-Image" software for analysis of digital seedling images, found that the digital method makes refined dimensional analysis feasible, with the possibility of adjusting the procedure for seedling analysis in maize and in other species.

It can also be seen in Table 5 that for the four methods of image analysis used, batches 4, 5 and 6 were

Table 5 - Mean root length $(\mathrm{cm})$ in maize seedlings from nine batches of Hybrid 1 for different methods of seedling image analysis using SAS, UFLA, Lavras, MG, Brazil, 2014

\begin{tabular}{ccccc}
\hline \multirow{2}{*}{ Batch } & \multicolumn{4}{c}{ Methods of image analysis using SAS } \\
\cline { 2 - 5 } & No NWF with correction & No NWF no correction & NWF with correction & NWF no correction \\
\hline 1 & $4.44 \mathrm{cA}$ & $4.44 \mathrm{cA}$ & $4.44 \mathrm{cA}$ & $4.44 \mathrm{cA}$ \\
2 & $2.25 \mathrm{cA}$ & $5.21 \mathrm{cA}$ & $5.05 \mathrm{bA}$ & $4.96 \mathrm{bA}$ \\
3 & $4.78 \mathrm{cA}$ & $4.73 \mathrm{cA}$ & $5.08 \mathrm{bA}$ & $5.10 \mathrm{bA}$ \\
4 & $7.66 \mathrm{aA}$ & $7.49 \mathrm{aB}$ & $6.47 \mathrm{aB}$ & $6.51 \mathrm{aB}$ \\
5 & $7.78 \mathrm{aA}$ & $7.76 \mathrm{aB}$ & $6.38 \mathrm{aB}$ & $6.32 \mathrm{aB}$ \\
6 & $7.13 \mathrm{aA}$ & $7.13 \mathrm{aA}$ & $6.93 \mathrm{aA}$ & $6.95 \mathrm{aA}$ \\
7 & $5.93 \mathrm{bA}$ & $6.01 \mathrm{bA}$ & $5.20 \mathrm{bB}$ & $5.27 \mathrm{bB}$ \\
8 & $6.15 \mathrm{bA}$ & $6.26 \mathrm{bA}$ & $4.92 \mathrm{bB}$ & $4.96 \mathrm{bB}$ \\
9 & $5.80 \mathrm{bA}$ & $5.85 \mathrm{bA}$ & $5.34 \mathrm{bA}$ & $5.41 \mathrm{bA}$ \\
\hline $\mathrm{CV}(\%)$ & & 9.22 & & \\
\hline
\end{tabular}

*Means followed by the same lowercase letter in a column and uppercase letter on a line do not differ by Scott-Knott test at a significance level of 5\% 
classified as of high vigour using the variable of mean root length. In a similar way, this was also observed in the results obtained when characterising the batches of Hybrid 1. From these results it is possible to state that mean seedling root length was an effective parameter in the evaluation of vigour in maize. Comparable results were obtained by Coimbra et al. (2009), who assessed the efficiency of different vigour tests in the evaluation of physiological quality in seeds of sweet corn.

From the results of mean seedling length, it was also possible to classify batches 4,5 and 6 as being of greater vigour than the other batches (Table 6). Similar results were obtained when classifying the nine batches of Hybrid 1 by traditional tests (Table 2), as observed for the variable, mean root length. Initial seedling length in this maize hybrid is therefore directly related to seed vigour; this also being reported by Mondo et al. (2013), who evaluated the effect of seed vigour on initial growth in maize seedlings.

For Hybrid 1, and using the results for mean coleoptile length, it was only possible to identify batches 1 and 3 as being of low vigour; this variable being less sensitive than mean root length in identifying differences in seed vigour in batches of this hybrid. This may have happened because the nine batches of Hybrid 1 showed high seed vigour, which results in greater uniformity of growth in the seedling shoots. According to Engli and Rucker (2012), seeds with high vigour present greater uniformity of seedling emergence. Thus for Hybrid 1, initial growth of the roots is more related to seed vigour in the hybrid than to initial growth of the seedling shoots.

From the automatic vigour index, manual vigour index and growth index, it was possible to classify batches 4, 5 and 6 of Hybrid 1 as being of high vigour; this classification being compatible with those obtained from the vigour tests used when characterising the batches (Table 2). Image analysis of maize seedlings by the SAS equipment was efficient in detecting differences in the vigour of batches of seeds from hybrid 1, in a similar way to the tests of accelerated ageing, cold, first count, seedling emergence at $25^{\circ} \mathrm{C}$ and to the emergence index of seedlings at 25 and $30^{\circ} \mathrm{C}$.

In studies, such as those of Alvarenga, Marcos Filho and Gomes Júnior (2012) with seeds of sweet corn, and Otoni and McDonald (2005) with seeds of common maize, it was possible to verify the efficiency of image analysis of seedlings in the evaluation of vigour using image analysis.

The uniformity index provided by the SAS, was not in itself an effective tool in evaluating the vigour of the nine batches of seeds of hybrid 1 , since it resulted in different classifications from that seen in the traditional

Table 6 - Image analysis of maize seedlings from the nine batches of Hybrid 1 using SAS: mean and total coleoptile length for the seedling, Automatic Vigour index (VA), Manual Vigour index (VM), Uniformity index (U) and Growth index (C ), UFLA, Lavras, MG, Brazil, 2014

\begin{tabular}{ccccccc}
\hline \multirow{2}{*}{ Batches } & \multicolumn{1}{c}{ Coleoptile } & Total & VA & VM & U & C \\
\cline { 2 - 6 } & $0.94 \mathrm{~b}$ & $5.41 \mathrm{e}$ & $88.2 \mathrm{~b}$ & $40.7 \mathrm{~d}$ & $78.1 \mathrm{a}$ & $24.7 \mathrm{~d}$ \\
\hline 1 & $1.16 \mathrm{a}$ & $6.29 \mathrm{c}$ & $88.7 \mathrm{~b}$ & $43.7 \mathrm{~b}$ & $79.0 \mathrm{a}$ & $28.5 \mathrm{c}$ \\
2 & $1.02 \mathrm{~b}$ & $5.95 \mathrm{~d}$ & $88.7 \mathrm{~b}$ & $42.5 \mathrm{c}$ & $78.3 \mathrm{a}$ & $27.2 \mathrm{c}$ \\
3 & $1.16 \mathrm{a}$ & $8.19 \mathrm{a}$ & $93.1 \mathrm{a}$ & $48.7 \mathrm{a}$ & $73.5 \mathrm{~b}$ & $38.1 \mathrm{a}$ \\
4 & $1.29 \mathrm{a}$ & $8.35 \mathrm{a}$ & $93.8 \mathrm{a}$ & $50.1 \mathrm{a}$ & $77.2 \mathrm{a}$ & $38.5 \mathrm{a}$ \\
5 & $0.23 \mathrm{a}$ & $8.26 \mathrm{a}$ & $93.1 \mathrm{a}$ & $49.1 \mathrm{a}$ & $74.5 \mathrm{~b}$ & $38.2 \mathrm{a}$ \\
6 & $1.25 \mathrm{a}$ & $6.85 \mathrm{~b}$ & $88.6 \mathrm{~b}$ & $45.0 \mathrm{~b}$ & $77.5 \mathrm{a}$ & $31.1 \mathrm{~b}$ \\
7 & $1.22 \mathrm{a}$ & $6.79 \mathrm{~b}$ & $88.7 \mathrm{~b}$ & $44.6 \mathrm{~b}$ & $76.5 \mathrm{a}$ & $30.9 \mathrm{~b}$ \\
9 & $1.21 \mathrm{a}$ & $6.81 \mathrm{~b}$ & $89.2 \mathrm{~b}$ & $44.4 \mathrm{~b}$ & $75.6 \mathrm{~b}$ & $31.0 \mathrm{~b}$ \\
\hline $\mathrm{CV}(\%)$ & 13.81 & 9.62 & 1.57 & 5.42 & 5.42 & 9.41 \\
\hline
\end{tabular}

* Means followed by the same letter in a column do not differ by Scott-Knott test at a significance level of 5\% 
tests used when characterising the batches. Uniformity of growth in maize seedlings is directly related to seed vigour, with seeds of high vigour displaying uniform emergence (ENGLI; RUCKER, 2012).

The use of blue NWF had a negative influence on the values for mean coleoptile and seedling lengths, and on the values for the manual vigour index and growth index (Table 7). Correction of part of the seedlings in the images did not change the results for most of the variables analysed using SAS. It can be seen therefore that there is no need for correction of the images analysed using the SAS equipment, with the possibility of reducing the time taken for completion of the process of image analysis.

For Hybrid 2, the methods of image analysis had a similar influence on all the variables analysed using SAS for the nine batches of maize seeds (Table 8). There was wide variation between the results using SAS in the classification of the nine batches of this hybrid, however this was also seen in the results of the tests used in characterising the batches (Table 3 ).

With the results for mean coleoptile length, it was possible to classify batches $\mathrm{D}, \mathrm{E}$ and $\mathrm{F}$ as being of low vigour; this result also being seen in the accelerated ageing and cold tests. As noted above, initial growth in the seedlings is directly related to the vigour of the maize seeds (MONDO et al., 2013). However, the results of the classification of the nine batches using the parameter of mean root length showed no similarities with the classification of vigour using tests evaluated when characterising the batches of Hybrid 2. Mean coleoptile length was more efficient in identifying vigour in the batches compared to mean root length, indicating that for this hybrid, growth of the shoots is related more to seed vigour than to the roots.

From the automatic vigour index it was possible to classify batches $\mathrm{D}, \mathrm{E}$ and $\mathrm{F}$ as being of low vigour, and batches $\mathrm{A}, \mathrm{B}$ and $\mathrm{C}$ as being of high vigour (Table 8); this classification being similar to those obtained with the accelerated ageing and cold tests (Table 3 ). The similarity of the results for the automatic vigour index to the results obtained with the cold test, show that the automatic calibration of the formula for vigour index using SAS was efficient, seeing as how the results of the cold test were used for the calibration.

The direct relationship of the cold test results to the automatic vigour index provided by the SAS is an important result for use of this equipment in evaluating the vigour of maize seeds. According to Noli et al. (2008), the cold test is that most used by maize-producing industries in evaluating the vigour of seed batches, however the test takes 14 days to get results, whereas analysis of seedling images using SAS requires only three days.

For Hybrid 2, the NWF influenced most values of the parameters under evaluation using SAS, however correction of the seedling images did not affect these results (Table 9). There is therefore no need for the use of colour in the substrate, nor for correction of the images of maize seedlings analysed by SAS.

Despite the differences found in the analyses of the two hybrids under evaluation - small adjustments related to the different behaviour of the genetic material as regards seedling growth - the SAS equipment can be considered promising in a quick and accurate evaluation of vigour in batches of maize seeds.

Table 7 - Image analysis of maize seedlings from Hybrid 1 for the different methods of seedling image analysis using SAS: mean and total coleoptile length for the seedling, Automatic Vigour index (VA), Manual Vigour index (VM), Uniformity index (U) and Growth index (C), UFLA, Lavras, MG, Brazil, 2014

\begin{tabular}{|c|c|c|c|c|c|c|}
\hline \multirow{2}{*}{$\begin{array}{c}\text { Method of Image } \\
\text { Analysis }\end{array}$} & \multicolumn{2}{|c|}{--------Length $(\mathrm{cm})$--------- } & \multicolumn{4}{|c|}{ 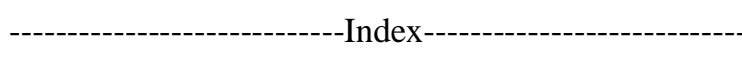 } \\
\hline & Coleoptile & Total & VA & VM & $\mathrm{U}$ & $\mathrm{C}$ \\
\hline no NWF with correction & $1.33 \mathrm{a}$ & $7.43 \mathrm{a}$ & $89.7 \mathrm{~b}$ & $47.5 \mathrm{a}$ & $79.3 \mathrm{a}$ & $30.1 \mathrm{a}$ \\
\hline no NWF no correction & $1.44 \mathrm{a}$ & $7.54 \mathrm{a}$ & $91.2 \mathrm{a}$ & $46.7 \mathrm{a}$ & $76.3 \mathrm{~b}$ & $30.1 \mathrm{a}$ \\
\hline NWF with correction & $0.96 \mathrm{~b}$ & $6.50 \mathrm{~b}$ & $89.2 \mathrm{~b}$ & $44.4 \mathrm{~b}$ & $77.8 \mathrm{~b}$ & $33.8 \mathrm{~b}$ \\
\hline NWF no correction & $0.93 \mathrm{~b}$ & $6.48 \mathrm{~b}$ & $90.8 \mathrm{a}$ & $43.1 \mathrm{c}$ & $73.4 \mathrm{c}$ & $34.1 \mathrm{~b}$ \\
\hline $\mathrm{CV}(\%)$ & 13.81 & 9.62 & 1.57 & 5.42 & 5.42 & 9.41 \\
\hline
\end{tabular}

*Means followed by the same letter in a column do not differ by Scott-Knott test at a significance level of 5\% 
Table 8 - Image analysis of maize seedlings from the nine batches of Hybrid 1 using SAS: mean coleoptile and root length and total length for the seedling, Automatic Vigour index (VA), Manual Vigour index (VM), Uniformity index (U) and Growth index (C ), UFLA, Lavras, MG, Brazil, 2014

\begin{tabular}{|c|c|c|c|c|c|c|c|}
\hline \multirow{2}{*}{ Batch } & \multicolumn{3}{|c|}{-----------------Length (cm)------------------ } & \multicolumn{4}{|c|}{ 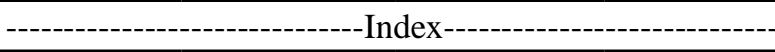 } \\
\hline & Coleoptile & Root & Total & VA & VM & $\mathrm{U}$ & $\mathrm{C}$ \\
\hline A & $1.17 \mathrm{~b}$ & $5.46 \mathrm{c}$ & $6.63 \mathrm{c}$ & $91.2 \mathrm{a}$ & $44.4 \mathrm{~b}$ & $77.6 \mathrm{a}$ & $30.2 \mathrm{c}$ \\
\hline $\mathrm{B}$ & $1.18 \mathrm{~b}$ & $5.18 \mathrm{c}$ & $6.36 \mathrm{c}$ & $92.4 \mathrm{a}$ & $43.5 \mathrm{~b}$ & $77.7 \mathrm{a}$ & $28.8 \mathrm{c}$ \\
\hline $\mathrm{C}$ & $1.18 \mathrm{~b}$ & $5.36 \mathrm{c}$ & $6.55 \mathrm{c}$ & $91.2 \mathrm{a}$ & $44.2 \mathrm{~b}$ & $77.8 \mathrm{a}$ & $29.8 \mathrm{c}$ \\
\hline $\mathrm{D}$ & $0.97 \mathrm{c}$ & $6.08 \mathrm{~b}$ & $7.04 \mathrm{~b}$ & $85.0 \mathrm{c}$ & $44.9 \mathrm{~b}$ & $73.3 \mathrm{~b}$ & $32.8 \mathrm{~b}$ \\
\hline $\mathrm{E}$ & $0.78 \mathrm{~d}$ & $5.36 \mathrm{c}$ & $6.14 \mathrm{c}$ & $83.9 \mathrm{c}$ & $41.2 \mathrm{c}$ & $70.3 \mathrm{~b}$ & $28.7 \mathrm{c}$ \\
\hline $\mathrm{F}$ & $1.06 \mathrm{c}$ & $6.22 \mathrm{~b}$ & $7.28 \mathrm{~b}$ & $84.0 \mathrm{c}$ & $45.2 \mathrm{~b}$ & $71.8 \mathrm{~b}$ & $33.8 \mathrm{c}$ \\
\hline $\mathrm{G}$ & $1.13 \mathrm{~b}$ & $5.98 \mathrm{~b}$ & $7.11 \mathrm{~b}$ & $87.8 \mathrm{~b}$ & $45.7 \mathrm{~b}$ & $76.0 \mathrm{a}$ & $32.7 \mathrm{~b}$ \\
\hline $\mathrm{H}$ & $1.35 \mathrm{a}$ & $6.45 \mathrm{a}$ & $7.80 \mathrm{a}$ & $88.9 \mathrm{~b}$ & $47.8 \mathrm{a}$ & $76.3 \mathrm{~b}$ & $35.6 \mathrm{a}$ \\
\hline I & $1.39 \mathrm{a}$ & $6.54 \mathrm{a}$ & $7.93 \mathrm{a}$ & $89.7 \mathrm{~b}$ & $48.5 \mathrm{a}$ & $77.2 \mathrm{~b}$ & $36.2 \mathrm{a}$ \\
\hline $\mathrm{CV}(\%)$ & 15.71 & 8.73 & 9.39 & 3.20 & 5.52 & 6.04 & 9.06 \\
\hline
\end{tabular}

*Means followed by the same letter in a column do not differ by Scott-Knott test at a significance level of $5 \%$

Table 9 - Image analysis of maize seedlings from Hybrid 2 for the different methods of seedling image analysis using SAS: mean coleoptile and root length and total length for the seedling, Automatic Vigour index (VA), Manual Vigour index (VM), Uniformity index (U) and Growth index (C), UFLA, Lavras, MG, Brazil, 2014

\begin{tabular}{lccccccc}
\hline \multirow{2}{*}{$\begin{array}{c}\text { Method of Image } \\
\text { Analysis }\end{array}$} & \multicolumn{3}{c}{ Length $(\mathrm{cm})$} & \multicolumn{3}{c}{ Index } \\
\cline { 2 - 7 } & Coleoptile & Root & Total & VA & VM & U & C \\
\hline no NWF with correction & $0.93 \mathrm{~b}$ & $5.18 \mathrm{~b}$ & $6.11 \mathrm{~b}$ & $89.0 \mathrm{a}$ & $43.0 \mathrm{~b}$ & $77.5 \mathrm{~b}$ & $28.2 \mathrm{~b}$ \\
no NWF no correction & $0.99 \mathrm{~b}$ & $5.21 \mathrm{~b}$ & $6.19 \mathrm{~b}$ & $89.2 \mathrm{a}$ & $42.6 \mathrm{~b}$ & $75.4 \mathrm{a}$ & $28.5 \mathrm{~b}$ \\
NWF with correction & $1.33 \mathrm{a}$ & $6.50 \mathrm{a}$ & $7.80 \mathrm{a}$ & $88.0 \mathrm{~b}$ & $47.7 \mathrm{a}$ & $75.5 \mathrm{a}$ & $35.8 \mathrm{a}$ \\
NWF no correction & $1.29 \mathrm{a}$ & $6.51 \mathrm{a}$ & $7.82 \mathrm{a}$ & $86.7 \mathrm{~b}$ & $46.9 \mathrm{a}$ & $72.8 \mathrm{~b}$ & $35.8 \mathrm{a}$ \\
\hline $\mathrm{CV}(\%)$ & 15.71 & 8.73 & 9.39 & 3.20 & 5.52 & 6.04 & 9.06 \\
\hline
\end{tabular}

*Means followed by the same letter in a column do not differ by Scott-Knott test at a significance level of $5 \%$

\section{CONCLUSIONS}

1. According to the methodologies for the analysis of seedling images studied in this research, the appropriate methodology to evaluate the physiological potential of maize seeds is to use seedlings obtained from sowing on white paper towel, at a temperature of $25{ }^{\circ} \mathrm{C}$ and with evaluation on the third day. Analysis of the image should be performed using the SAS equipment with automatic calibration, without the need to correct the seedling images;

2. Analysis of seedling images using SAS equipment is a potential tool in the evaluation of the physiological quality of maize seeds.

\section{ACKNOWLEDGEMENTS}

The authors would like to thank the Coordination for the Training of Personnel in Higher Education (CAPES) and National Council for Scientific and Technological Development (CNPq).

\section{REFERENCES}

ALVARENGA, R. O.; MARCOS FILHO, J.; GOMES JUNIOR, F. G. Avaliação do vigor de sementes de milho super doce por meio da análise computadorizada de imagens de plântulas. Revista Brasileira de Sementes, v. 34, n. 3, p. 488-494, 2012. 
ASSOCIATION OF OFFICIAL SEED ANALYSTS. Seed vigor testing handbook. Lincoln, 2009. 105 p. (Contribuition, 32).

BRASIL. Ministério da Agricultura Pecuária e Abastecimento. Padrões para produção e comercialização de sementes de milho cultivares híbrida. Disponível em: <http://www. agricultura.pr.gov.br/arquivos/File/PDF/padroes_ milho.pdf>. Acesso em: 12 nov. 2013.

BRASIL. Ministério da Agricultura, Pecuária e Abastecimento. Regras para análise de sementes. Brasília: SNDA/DNDV/ CLAV, 2009. 365 p.

CALIARI, M. F.; SILVA, W. R. da. Interpretação de dados de testes de vigor na avaliação da qualidade fisiológica de sementes de milho. Revista Brasileira de Sementes, v. 23, n. 1, p. 239-251, 2001.

COIMBRA, R. A. et al. Testes de vigor utilizados na avaliação da qualidade fisiológica de lotes de sementes de milho-doce (sh2). Ciência Rural, v. 39, n. 9, p. 2402-2408, 2009.

COMPANHIA NACIONAL DE ABASTECIMENTO. Acompanhamento da safra brasileira de grãos: segundo levantamento safra 2013/14. Brasília, 2013. 53 p.

EGLI, D. B.; RUCKER, M. Seed vigor and the uniformity of emergence of corn seedlings. Crop Science, v. 52, n. 1, p. 2774-2782, 2012.

FESSEL, S. A. et al. Avaliação da qualidade física, fisiológica e sanitária de sementes de milho durante o beneficiamento. Revista Brasileira de Sementes, v. 25, n. 2, p. 70-76, 2003.

ILLIPRONTI JUNIOR, R. A. Variation in quality of individual seeds within a seed lot of soybean [Glycine $\max (\mathrm{L}$.) Merrill]. 1997. 157 p. Thesis (Ph.D. in Landbouw) - Wageningen University, Wageningen, 1997.

MARCHI, J. L.; CICERO, S. M.; GOMES JUNIOR, F. G. Utilização da análise computadorizada de plântulas na avaliação do potencial fisiológico de sementes de amendoim tratadas com fungicida e inseticida. Revista Brasileira de Sementes, v. 33, n. 4, p. 652-662, 2011.

MARCOS FILHO, J.; KIKUTI, A. L. P.; LIMA, L. B. Métodos para avaliação do vigor de sementes de soja, incluindo a análise computadorizada de imagens. Revista Brasileira de Sementes, v. 31, n. 1, p. 102-112, 2009.

MCDONALD, M. B. et al. System and method for determining a seed vigor index from germinated seedlings by automatic separation of overlapped seedlings. US n. 7.372.978 B2, 13 May 2008. Columbus: Ohio State University Research Foundation, 2008.

MONDO, V. H. V. et al. Seed vigor and initial growth of corn crop. Journal of Seed Science, v. 35, n. 1, p. 64-69, 2013.

NOLI, E. et al. Suitability of three vigour test procedures to predict field performance of early sown maize seed. Seed Science and Tecnology, v. 36, n. 1, p. 168-176, 2008.

OTONI, R. R.; MCDONALD, M. B. Moisture and temperature effects on maize and soybean seedlings using the seed vigor imaging system. Seed Science and Technology, v. 27, n. 2, p. 243-247, 2005.

PINHO, E. V. R. Von et al. Efeitos no tratamento fungicida sobre a qualidade sanitária e fisiológica de sementes de milho (Zea mays L.). Revista Brasileira de Sementes, v. 17, n. 1, p. 23-28, 1995.

SAKO, Y. et al. A system for automated seed vigour assessment. Seed Science and Technology, v. 29, n. 3, p. 625-636, 2001.

SILVA, V. N.; GOMES JUNIOR, F. G.; CICERO, S. M. Computerized maging analysis of seedlings for assessment of physiological potential of wheat seeds. Revista Brasileira de Sementes, v. 34, n. 4, p. 589-596, 2012.

TEIXEIRA, E. F.; CICERO, S. M.; DOURADO NETO, D. Análise de imagens digitais de plântulas para avaliação do vigor de sementes de milho. Revista Brasileira de Sementes, v. 28 , n. 2, p. 159-167, 2006.

TEKRONY, D. M. Precision is an essential component in seed vigour testing. ISTA New Bulletin, v. 31, n. 2, p. 435-447, 2003.

TEKRONY, D. M.; EGLI, D. B.; WICKHAM, D. A. Corn seed vigor effect on no-tillage field performance: II., plant growth and grain yield. Crop Science, v. 29, p. 1528-1531, 1989. 